\title{
EFEKTIVITAS MODEL PEMBELAJARAN PREDICT, OBSERVE, EXPLAIN (POE) PADA PEMBELAJARAN MATEMATIKA SISWA KELAS VII SMP NEGERI SELANGIT
}

\author{
Dina Mitasari ${ }^{1}$, Idul Adha ${ }^{2}$, Nur Fitriyana ${ }^{3}$ \\ ${ }^{\prime}$ STKIP PGRI Lubuklinggau, Indonesia, dinamitasari25@gmail.com \\ ${ }^{2}$ STKIP PGRI Lubuklinggau, Indonesia, idul adha12@yahoo.com \\ 33TKIP PGRI Lubuklinggau, Indonesia, nurfi3ana@gmail.com
}

\section{ARTICLE INFORMATION}

Received: October 10, 2019

Revised: December 26, 2019

Available online: December 31, 2019

KEYWORDS

Efektivitas, Pembelajaran, POE

Effectiveness, Learning, POE

CORRESPONDENCE

IDUL ADHA

E-mail: $\underline{\text { idul_adha12@yahoo.com }}$

\section{A $\quad$ B $\quad \mathbf{S} \quad \mathbf{T} \quad \mathbf{R}$ A $\mathbf{C}$ T}

Penelitian ini bertujuan untuk mengetahui efektivitas model pembelajaran Predict, Observe, Explain (POE) pada pembelajaran matematika siswa kelas VII SMP Negeri Selangit. Penelitian ini berbentuk eksperimen semu. Populasinya adalah seluruh siswa kelas VII SMP Negeri Selangit tahun pelajaran 2019/2020 yang berjumlah 98 siswa dan sebagai sampelnya adalah siswa kelas VII.3 yang berjumlah 24 siswa. Pengumpulan data dilakukan dengan teknik tes dan non tes. Data yang sudah terkumpul dianalisis menggunakan uji-t pada taraf signifikan $\alpha=0,05$. Berdasarkan hasil penelitian menunjukkan efektivitas model pembelajaran Predict, Observe, Explain (POE) pada pembelajaran matematika dengan skor ratarata 74,44 dengan persentase jumlah siswa yang tuntas sebesar $79,17 \%$ respon siswa terhadap pembelajaran dalam kategori baik dengan persentase sebesar $72,44 \%$, dan aktivitas pembelajaran siswa dalam kategori cukup aktif dengan persentase sebesar $28,45 \%$.

This study aims to determine the effectiveness of the Predict, Observe, Explain (POE) learning model in mathematics learning for VII grade students of SMP Negeri Selangit. This research is in the form of quasi-experimental. The population is all grade VII students of SMP Negeri Selangit in the academic year 2019/2020, totaling 98 students and as a sample are class VII.3 students, amounting to 24 students. Data collection is done by test and non-test techniques. The collected data were analyzed using t-test at a significant level $\alpha=0.05$. Based on the results of the study showed the effectiveness of the Predict, Observe, Explain (POE) learning model in mathematics learning with an average score of 74.44 with the percentage of students completing $79.17 \%$ of students' responses to learning in the good category with a percentage of $72.44 \%$, and student learning activities in the quite active category with a percentage of $28.45 \%$.

\section{PENDAHULUAN}

Efektivitas pembelajaran merupakan suatu ukuran yang berhubungan dengan tingkat keberhasilan dari suatu proses pembelajaran. Menurut Sumantri (2015:1) menyatakan bahwa efektivitas adalah seberapa jauh target (kuantitas, kualitas dan waktu) yang telah dicapai oleh manajemen, yang mana target tersebut sudah ditentukan terlebih dahulu.

Menurut Rohmawati (2015:17) efektivitas pembelajaran merupakan suatu ukuran keberhasilan dari proses interaksi dalam situasi edukatif untuk mencapai tujuan pembelajaran terhadap hasil belajar siswa.

Menurut Abdurahman (2012:37) mengatakan bahwa hasil belajar yaitu kemampuan yang diperoleh anak setelah melalui kegiatan belajar. menurut Simanjuntak \& Imelda (Efendi, 2016:88) bahwa di dalam belajar adanya perubahan tingkah laku berdasarkan pengalaman, sehingga adanya interaksi antara stimulus dan respon. 


\section{Journal of Mathematics Science and Education \\ | ISSN (Print) 2623-2375 | ISSN (Online) 2623-2383 | \\ DOI : https://doi.org/10.31540/jmse.v2i2.528 \\ Penerbit : LP4MK STKIP PGRI Lubuklinggau}

Menurut Lestari \& Yudhanegara (2015:93) respon adalah suatu sikap yang menunjukkan adanya partisipasi aktif untuk melibatkan diri dalam suatu kegiatan pembelajaran. Adapun indikator respon siswa yang akan digunakan peneliti dalam penelitian ini yaitu dapat dilihat pada tabel 1 berikut:

Tabel 1

Indikator Respon

\begin{tabular}{|c|c|c|}
\hline No & Aspek & Indikator \\
\hline \multirow[t]{2}{*}{1} & \multirow[t]{2}{*}{$\begin{array}{l}\text { Respon siswa terhadap } \\
\text { pelajaran matematika }\end{array}$} & $\begin{array}{l}\text { Menunjukkan minat terhadap pelajaran matematika dengan } \\
\text { menggunakan model POE. }\end{array}$ \\
\hline & & $\begin{array}{l}\text { Menunjukkan kegunaan terhadap pelajaran matematika } \\
\text { dengan menggunakan model POE. }\end{array}$ \\
\hline \multirow[t]{2}{*}{2} & \multirow[t]{2}{*}{$\begin{array}{l}\text { Respon siswa terhadap cara } \\
\text { guru mengajar }\end{array}$} & $\begin{array}{l}\text { Menunjukkan perasaan siswa dalam menilai cara guru } \\
\text { mengajar dengan menggunakan modelPOE. }\end{array}$ \\
\hline & & $\begin{array}{l}\text { Menunjukkan perasaan siswa dalam menilai suasana kelas } \\
\text { dengan menggunakan model POE. }\end{array}$ \\
\hline \multirow[t]{3}{*}{3} & \multirow{3}{*}{$\begin{array}{lr}\text { Sikap siswa } & \text { terhadap } \\
\text { pembelajaran } & \text { dengan } \\
\text { menggunakan model } & \text { POE }\end{array}$} & $\begin{array}{l}\text { Menunjukkan minat terhadap pembelajaran matematika } \\
\text { dengan model POE. }\end{array}$ \\
\hline & & $\begin{array}{l}\text { Menunjukkan kegunaan mengikuti pembelajaran matematika } \\
\text { dengan menggunakan model POE. }\end{array}$ \\
\hline & & $\begin{array}{l}\text { Menunjukkan minat siswa mengikuti kegiatan pembelajaran } \\
\text { berikutnya seperti yang telah diikuti sekarang. }\end{array}$ \\
\hline
\end{tabular}

(Modifikasi Baroh, 2013:36)

Sama halnya dengan respon siswa, keaktifan dalam belajar juga merupakan salah satu faktor yang dapat mempengaruhi keberhasilan siswa dalam belajar. Aktivitas belajar sangat mendukung terlaksananya suatu proses pembelajaran yang mandiri, artinya pembelajaran yang baik membutuhkan keaktifan siswa seperti mengerjakan tugas, menanggapi pertanyaan dari guru, mendengarkan penjelasan, dan melakukan percobaan (Prasetyo \& Rabiman 2015:684). Adapun indikator aktivitas belajar siswa yang diambil yaitu sebagai berikut: 1) Mengajukan pertanyaan; 2) Menjawab pertanyaan; 3) Menanggapi pendapat orang lain; 4) Mengajukan pendapat; 5) Menulis dan 6) Memperhatikan/mendengarkan.

Dilihat dari hasil belajar siswa dari jumlah 114 siswa hanya 29 siswa atau sebanyak $25 \%$ yang telah mencapai nilai Ketuntasan Belajar Minimal (KBM). Ketuntasan Belajar Minimal (KBM) yang terdapat di sekolah tersebut adalah 65 dan siswa yang belum mencapai nilai KBM sebanyak 85 siswa atau $75 \%$. Untuk mengatasi permasalahan tersebut maka diperlukan model pembelajaran yang dapat menciptakan kondisi aktif, kreatif, efektif dan menyenangkan bagi siswa. Salah satu alternatifnya adalah dengan menerapkan model pembelajaran Predict, Observe, Explain (POE).

Model pembelajaran Predict, Observe, Explain (POE) merupakan suatu rangkaian kegiatan penyampaian materi pelajaran yang bertujuan memberi kesempatan kepada siswa untuk aktif 


\section{Journal of Mathematics Science and Education \\ | ISSN (Print) 2623-2375 | ISSN (Online) 2623-2383 | \\ DOI : https://doi.org/10.31540/jmse.v2i2.528 \\ Penerbit : LP4MK STKIP PGRI Lubuklinggau}

belajar sehingga memungkinkan siswa memperoleh pengetahuan dan mengembangkan keterampilan kognitif dan manual (Hidayati, 2016:58). Model Pembelajaran Predict, Observe, Explain (POE) ini dinyatakan sebagai pembelajaran yang efisien untuk memperoleh dan meningkatkan konsepsi sains siswa, serta dapat menimbulkan ide atau gagasan siswa dan melakukan diskusi dari ide-ide mereka (Indriana dkk., 2015:54). Dengan model pembelajaran Predict, Observe, Explain (POE), hasil pembelajaran diharapkan dapat meningkatkan kemampuan bernalar dan lebih bermakna bagi siswa. Proses pembelajaran ini berlangsung alamiah bukan hanya sekedar transfer pengetahuan dari guru kepada siswa melainkan dalam bentuk kegiatan siswa bekerja dan mengalami secara langsung saat proses pembelajaran berlangsung

Berdasarkan uraian di atas, tujuan penelitian ini adalah untuk mengetahui efektivitas model pembelajaran predict, observe, explain (poe) pada pembelajaran matematika siswa kelas VII SMP Negeri Selangit.

\section{METODE}

Dalam penelitian ini, peneliti menggunakan metode eksperimen semu (quasi experiment) kategori Pre-test and Post-test Group. Menurut Arikunto (2010:124) desain Pre-test and Post-test Group dilakukan sebanyak 2 kali yaitu sebelum eksperimen Pre-test dan sesudah eksperimen Posttest. Pada penelitian ini teknik pengambilan sampel yang digunakan adalah simple random sampling (cara random sederhana) yang dilakukan secara acak tanpa melihat strata pada populasi itu dengan cara mengundi semua kelas dari 4 kelas yang ada, sehingga didapat satu kelas sebagai sampel dan yang diberikan perlakuan berupa pembelajaran dengan model pembelajaran Predict, Observe, Explain (POE). Kelas terpilih sebagai sampel adalah kelas VII.3 dengan jumlah siswa sebanyak 24 orang.

Teknik pengumpulan data yang digunakan peneliti di dalam penelitian adalah teknik tes dan non tes. Jenis data yang terkumpul dari penelitian ini berupa data kuantitatif dan kualitatif. Data kuantitatif adalah data yang diperoleh dari nilai siswa setelah mengikuti pembelajaran dengan model Predict, Observe, Explain (POE) untuk mengetahui hasil belajar matematika siswa. Sedangkan data kualitatif yaitu data tentang respon siswa terhadap model Predict, Observe, Explain (POE) dan data aktivitas siswa yang mengikuti pembelajaran dengan model Predict, Observe, Explain (POE). 


\section{Journal of Mathematics Science and Education \\ | ISSN (Print) 2623-2375 | ISSN (Online) 2623-2383 | \\ DOI : https://doi.org/10.31540/jmse.v2i2.528 \\ Penerbit : LP4MK STKIP PGRI Lubuklinggau}

\section{Teknik Tes}

Menurut Arikunto (2010:193) Tes adalah serentetan pernyataan atau latihan serta alat lain yang digunakan untuk mengukur keterampilan, pengetahuan inteligensi, kemampuan atau bakat yang dimiliki oleh individu atau kelompok. Teknik tes digunakan oleh peneliti untuk mengumpulkan data tentang hasil belajar siswa dengan mengunakan model pembelajaran Predict, Observe, Explain (POE). Teknik tes yang dilakukan peneliti sebanyak dua kali yaitu tes awal (Pre-test) dan tes akhir (Post-test). Tes yang diberikan pada penelitian ini berbentuk soal esai yaitu sebanyak 6 soal yang diberikan kepada siswa guna mengetahui tingkat keberhasilan model pembelajaran yang digunakan.

2. Teknik Non Tes

a. Angket yang digunakan dalam penelitian ini adalah angket respon siswa dalam mengikuti pembelajaran matematika dengan menggunakan model pembelajaran Predict, Observe, Explain (POE). Angket tersebut berbentuk checklist $(\sqrt{ })$ dan berisi 20 pertanyaan untuk menjaring informasi dari responden. Data yang dikumpulkan akan menggunakan skala likert dan diambil persentasenya.

b. Observasi yang dilakukan dalam penelitian ini terdiri dari observasi siswa. Observasi siswa dilakukan di kelas VII.3 SMP Negeri Selangit selama pemberian perlakuan pembelajaran matematika dengan menggunakan model Predict, Observe, Explain (POE). Observasi siswa terdiri dari enam indikator dan diamati setiap 15 menit.

\section{HASIL DAN PEMBAHASAN}

Sebelum pelaksanaan Pre-test makam Intrumen soal diujicobakan terlebih dahulu. Berdasarkan hasil perhitungan uji coba instrumen tersebut, maka diperoleh rekapitulasi hasil uji coba instrumen yang terdapat pada tabel 2 berikut.

Tabel 2

Hasil Analisis Uji Coba Instrumen

\begin{tabular}{|c|c|c|c|c|c|c|c|c|}
\hline No & \multicolumn{2}{|c|}{ Validitas } & Reliabilitas & \multicolumn{2}{|c|}{ Daya Pembeda } & \multicolumn{2}{|c|}{ Indeks Kesukaran } & Keterangan \\
\hline 1 & 0,49 & Validitas & \multirow{6}{*}{$\begin{array}{c}0,51 \\
\text { (Sedang) }\end{array}$} & 0,08 & Jelek & 0,95 & Mudah & Digunakan \\
\hline 2 & 0,55 & Validitas & & 0,18 & Jelek & 0,67 & Sedang & Digunakan \\
\hline 3 & 0,52 & Validitas & & 0,23 & Cukup & 0,87 & Mudah & Digunakan \\
\hline 4 & 0,62 & Validitas & & 0,23 & Cukup & 0,87 & Mudah & Digunakan \\
\hline 5 & 0,64 & Validitas & & 0,12 & Jelek & 0,32 & Sedang & Digunakan \\
\hline 6 & 0,59 & Validitas & & 0,26 & Cukup & 0,20 & Sukar & Digunakan \\
\hline
\end{tabular}




\section{Journal of Mathematics Science and Education \\ | ISSN (Print) 2623-2375 | ISSN (Online) 2623-2383 | \\ DOI : https://doi.org/10.31540/jmse.v2i2.528 \\ Penerbit : LP4MK STKIP PGRI Lubuklinggau}

Berdasarkan rekapitulasi hasil uji coba instrumen penelitian pada tabel 2 di atas dapat disimpulkan bahwa soal yang dapat digunakan adalah sebanyak enam soal yaitu soal nomor 1, 2, 3, 4, 5, dan 6 .

\section{Data Hasil Pre-test}

Berdasarkan hasil perhitungan rekapitulasi data hasil pre-test dapat dilihat pada tabel 3 berikut ini.

Tabel 3

Rekapitulasi Data Hasil Pre-Test

\begin{tabular}{|c|c|c|c|c|}
\hline $\bar{x}$ & $\begin{array}{c}\text { Nilai } \\
\text { Max }\end{array}$ & $\begin{array}{c}\text { Nilai } \\
\text { Min }\end{array}$ & Siswa yang Tuntas & $\begin{array}{c}\text { Siswa yang Belum } \\
\text { Tuntas }\end{array}$ \\
\hline 17,36 & 30 & 6,66 & $\begin{array}{c}0 \text { Orang } \\
(0 \%)\end{array}$ & $\begin{array}{c}24 \text { Orang } \\
(100 \%)\end{array}$ \\
\hline
\end{tabular}

Berdasarkan tabel 3 secara deskriptif dapat disimpulkan bahwa kemampuan awal siswa kelas VII.3 SMP Negeri Selangit sebelum pelaksanaan pembelajaran matematika dengan menggunakan model Predict, Observe, Explain (POE) belum tuntas.

\section{Data Hasil Post-test}

Tabel 4

Rekapitulasi Data Hasil Post-Test

\begin{tabular}{|c|c|c|c|c|c|}
\hline $\bar{x}$ & $S$ & $\begin{array}{c}\text { Nilai } \\
\text { Max }\end{array}$ & $\begin{array}{c}\text { Nilai } \\
\text { Min }\end{array}$ & $\begin{array}{c}\text { Siswa yang } \\
\text { Tuntas }\end{array}$ & $\begin{array}{c}\text { Siswa yang } \\
\text { Belum Tuntas }\end{array}$ \\
\hline 74,44 & 10,57 & 100 & 60 & $\begin{array}{c}19 \\
(79,17 \%)\end{array}$ & $\begin{array}{c}5 \\
(20,83 \%)\end{array}$ \\
\hline
\end{tabular}

Berdasarkan tabel 4 diatas secara deskriptif dapat disimpulakan bahwa kemampuan akhir siswa pada kelas VII.3 SMP Negeri Selangit sesudah pelaksanaan pembelajaran matematika menggunakan model Predict, Observe, Explain (POE) termasuk dalam kategori tuntas.

Perbandingan rata-rata nilai pre-test dan post-test dapat dilihat pada grafik 1.

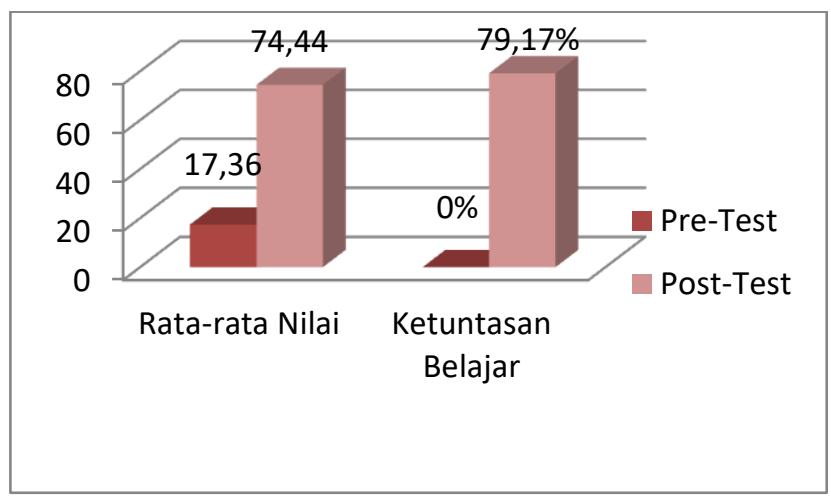

Grafik 1. Rata-Rata Nilai dan Ketuntasan Belajar 


\section{Data Hasil Respon Siswa}

Berdasarkan hasil perhitungan rekapitulasi hasil perhitungan angket respon siswa dapat dilihat pada tabel 5 .

Tabel 5

Rekapitulasi Hasil Analisis Angket Respon Siswa

\begin{tabular}{|c|c|c|c|c|}
\hline No. & Pernyataan & Skor & $\begin{array}{c}\text { Rata- } \\
\text { rata }\end{array}$ & $\%$ \\
\hline 1. & Saya senang belajar matematika & 82 & 3,42 & 85,4 \\
\hline 2. & $\begin{array}{l}\text { Saya terpaksa belajar matematika karena merupakan salah satu pelajaran yang } \\
\text { wajib diikuti }\end{array}$ & 80 & 3,33 & 83,3 \\
\hline 3. & Saya memiliki kemauan tinggi untuk mengikuti pelajaran matematika & 77 & 3,21 & 80,2 \\
\hline 4. & Masalah yang diberikan membuat saya bingung dengan materi & 76 & 3,17 & 79,2 \\
\hline 5. & Materi yang diajarkan kurang bermanfaat dalam kehidupan sehari-hari. & 73 & 3,04 & 76 \\
\hline 6. & Pelajaran matematika sangat bermanfaat dalam kehidupan sehari-hari & 75 & 3,13 & 78,1 \\
\hline 7. & Saya merasa tertekan dan tegang selama kegiatan belajar berlangsung & 63 & 2,63 & 65,6 \\
\hline 8. & $\begin{array}{l}\text { Suasana pembelajaran di kelas sangat menyenangkan dengan cara belajar yang } \\
\text { diterapkan oleh guru }\end{array}$ & 74 & 3,08 & 77,1 \\
\hline 9. & Guru memberikan perhatian selama proses belajar berlangsung & 76 & 3,17 & 79,2 \\
\hline 10. & $\begin{array}{l}\text { Saya tidak berminat mengikuti pembelajaran matematika seperti yang saya ikuti } \\
\text { saat ini }\end{array}$ & 64 & 2,67 & 66,7 \\
\hline 11. & $\begin{array}{l}\text { Langkah-langkah penyelesaian masalah dari soal membuat saya memahami } \\
\text { materi }\end{array}$ & 69 & 2,88 & 71,9 \\
\hline 12. & Saya menjadi termotivasi untuk berprestasi dalam pembelajaran matematika & 70 & 2,92 & 72,9 \\
\hline 13. & $\begin{array}{l}\text { Pembelajaran matematika seperti ini membuat saya lebih berani mengemukakan } \\
\text { pendapat }\end{array}$ & 71 & 2,96 & 74 \\
\hline 14. & Kegiatan berkelompok memudahkan saya bersosialisasi dengan teman & 67 & 2,79 & 69,8 \\
\hline 15. & Saya senang belajar matematika dengan berkelompok & 67 & 2,96 & 69,8 \\
\hline 16. & $\begin{array}{l}\text { Dengan adanya diskusi kelompok saya merasa kesulitan dalam menyelesaikan } \\
\text { masalah matematika }\end{array}$ & 58 & 2,42 & 60,4 \\
\hline 17. & $\begin{array}{l}\text { Belajar dengan menggunakan model Predict, Observe, Explain (POE) dapat } \\
\text { memecahkan permasalahan yang diberikan guru }\end{array}$ & 74 & 3,08 & 77,1 \\
\hline 18. & $\begin{array}{l}\text { Bagi saya belajar matematika dengan menggunakan model Predict, Observe, } \\
\text { Explain (POE)tidak berbeda dengan pembelajaran biasannya }\end{array}$ & 57 & 2,38 & 59,4 \\
\hline 19. & $\begin{array}{l}\text { Variasi, kegiatan, tugas, soal latihan dan lain-lain membantu saya } \\
\text { mengembangkan kemampuan pemecahan masalah matematika saya }\end{array}$ & 67 & 2,96 & 69,8 \\
\hline 20. & $\begin{array}{l}\text { Saya berminat untuk mengikuti kegiatan belajar berikutnya seperti yang telah } \\
\text { saya ikuti sekarang ini }\end{array}$ & 69 & 2,88 & 71,9 \\
\hline \multicolumn{2}{|c|}{ Rata-Rata } & & 2,90 & 72,44 \\
\hline \multicolumn{2}{|c|}{ Kriteria Respon Siswa } & \multicolumn{3}{|c|}{ Baik } \\
\hline
\end{tabular}




\section{Journal of Mathematics Science and Education \\ | ISSN (Print) 2623-2375 | ISSN (Online) 2623-2383 | \\ DOI : https://doi.org/10.31540/jmse.v2i2.528 \\ Penerbit : LP4MK STKIP PGRI Lubuklinggau}

\section{Data Hasil Observasi Aktivitas Siswa}

Berdasarkan hasil perhitungan rekapitulasi hasil observasi siswa yang dilakukan sebanyak tiga kali pertemuan dapat dilihat pada tabel 6 berikut ini.

Tabel 6

Rekapitulasi Hasil Analisis Data Observasi Aktivitas Siswa

\begin{tabular}{|c|c|c|c|c|c|c|c|}
\hline \multirow[b]{2}{*}{$\begin{array}{l}\text { Kategori } \\
\text { Aktivitas }\end{array}$} & \multicolumn{2}{|c|}{ Pertemuan I } & \multicolumn{2}{|c|}{ Pertemuan II } & \multicolumn{2}{|c|}{ Pertemuan III } & \multirow[b]{2}{*}{ Interpretasi } \\
\hline & $\begin{array}{l}\text { Jumlah } \\
\text { (siswa) }\end{array}$ & $\%$ & $\begin{array}{l}\text { Jumlah } \\
\text { (siswa) }\end{array}$ & $\%$ & $\begin{array}{l}\text { Jumlah } \\
\text { (siswa) }\end{array}$ & $\%$ & \\
\hline Sangat Aktif & 0 & $0 \%$ & 5 & $20,83 \%$ & 14 & $58,33 \%$ & Meningkat \\
\hline Aktif & 3 & $12,50 \%$ & 7 & $29,16 \%$ & 8 & $33,33 \%$ & Meningkat \\
\hline Cukup Aktif & 12 & $50,00 \%$ & 12 & $50,00 \%$ & 2 & $8,33 \%$ & Menurun \\
\hline Kurang Aktif & 9 & $37,50 \%$ & 0 & $0 \%$ & 0 & $0 \%$ & Menurun \\
\hline
\end{tabular}

\section{KESIMPULAN}

Berdasarkan hasil penelitian dan pembahasan, makapembelajaran matematika siswa kelas VII SMP Negeri Selangit setelah mengikuti pembelajaran matematika dengan menggunakan model Predict, Observe, Explain (POE) dapat peneliti simpulkan bahwa: 1) Hasil belajar matematika siswa kelas VII SMP Negeri Selangit setelah mengikuti pembelajaran matematika dengan menggunakan model Predict, Observe, Explain (POE) secara signifikan tuntas dengan rata-rata nilai post-test sebesar 74,$44 ; 2)$ Siswa sangat antusiasmengikuti pembelajaran matematika menggunakan model Predict, Observe, Explain (POE), respon siswa yang baik ditunjukan pada angket respon siswa yang mendapatkan hasil rata-rata sebesar 72,44\%; dan 3) Aktivitas siswa semakin meningkat setiap pertemuan. Pertemuan pertama persentase rata-rata aktivitas siswa sebesar $31,1 \%$ ini menunjukan bahwa siswa cukup aktif, pada pertemuan kedua persentase rata-rata aktivitas siswa sebesar $64,6 \%$ ini menunjukan bahwa siswa aktif dan pada pertemuan ketiga persentase rata-rata aktivitas siswa sebesar 75\% ini menunjukan bahwa siswa aktif.

Dengan demikian dapat disimpulkan bahwa model pembelajaran Predict, Observe, Explain (POE) efektif digunakan pada pembelajaran matematika siswa, respon siswa dan aktivitas siswa dalam pembelajaran matematika.

\section{DAFTAR RUJUKAN}

Abdurrahman. (2010). Pengantar dan Pengenalan Matematika. Jakarta: Rosdakarya.

Arikunto. (2010). Prosedur Penelitian Suatu Pendekatan Praktik. Jakarta: Rineka Cipta. 
Baroh. (2010). Efektivitas Metode Simulasi Pada Materi Peluang Siswa kelas IX SMP Negeri 1 Semarang. Jurnal UIN Sunan Ampel Surabaya. 3(1), 14-25.

Fitriyana, Nur. (2016). Penerapan Model Pembelajaran Kooperatif Teknik Two stay two stray pada

Sub Pokok Bahasan Persegi Panjang dan Persegi untuk meningkatkan Hasil Belajar Siswa Kelas VII SMPIT Miftahul Jannah. 130-134. Lubuklinggau: STKIP PGRI Lubuklinggau.

Friansah, D., Adha, I., \& Refianti, R. (2018). Pengembangan Pocket Book Berbasis Pendekatan Matematika Realistik Indonesia (PMRI) Materi Bangun Ruang Sisi Datar. Jurnal Pendidikan Matematika (Judika Education). 1(1), 1-10.

Hidayati, Nur. (2016). Upaya Peningkatan Prestasi Belajar Matematika melalui Penerapan Model Pembelajaran Predict-Observe-Explain (POE) kelas III SDN Samberan kec. Kanor kab. Bojonegoro. Jurnal KaryaPendidikan.2(3), 58-65.

Indriana, dkk.(2015). Penerapan Pendekatan Pembelajaran POE (Predict-Observe-Explain) untuk Meningkatkan Kemampuan Berpikir kreatif siswa kelas XI IPA-1 SMAN Makassar. DAYA MATEMATIS, 3(1), 14-25.http://docplayer.info/32960372-Jurnal-daya-matematis-volume-3nomor-1-maret-2015.html. [diakses tanggal 12 Desember 2018].

Lestari, Kurnia Eka dan Mokhammad Ridwan Yudhanegara. (2015). Penelitian Pendidikan Matematika. Bandung: PT Refika Aditama.

Prasetyo \& Rabiman. (2015). Penerapan Metode Diskusi dengan bantuan Media Animasi untuk meningkatkan Keaktifan dan Hasil belajar mata diklat motor sistem bahan bakar Siswa kelas XI SMK Muhammadiyah gamping Tahun ajaran 2014/2015. Jurnal Taman Vokasi, 3(2), 1425 .

Pratinuari, Karina. 2013. Keefektifan Pendekatan Open-Ended dengan Pembelajaran Kontekstual terhadap Kemampuan Berfikir Kreatif. Unnes Journal of Mathematics Education, 2(1), 105113.

Rohmawati, Afifatu. (2015). Efektivitas Pembelajaran. Jurnal Pendidikan Usia Dini, 9(1), 18-29.

Simanjuntak, Imelda. (2018). Respon Siswa terhadap Pembelajaran Matematika Realistik dengan konteks Budaya Batak Toba. MES (Journal of Mathematics Education and Science), 4(1), 1930 .

Sumantri, M. S. (2015). Strategi Pembelajaran Teori dan Praktik di Tingkat Pendidikan Dasar. Jakarta: Rajawali Pres. 